Otterbein University

Digital Commons @ Otterbein

$1-2011$

\title{
Why a Black Baptist Community Uses Christian Media: An Ethnographic Treatment of a Working-Class Community where Christian Media Use is Shaped by Sacred Tenets, Social Influences and Personal Factors
}

Eric K. Jones

Otterbein University, ejones@otterbein.edu

Follow this and additional works at: https://digitalcommons.otterbein.edu/comm_fac

Part of the Communication Commons

\section{Repository Citation}

Jones, Eric K., "Why a Black Baptist Community Uses Christian Media: An Ethnographic Treatment of a Working-Class Community where Christian Media Use is Shaped by Sacred Tenets, Social Influences and Personal Factors" (2011). Communications Faculty Scholarship. 7.

https://digitalcommons.otterbein.edu/comm_fac/7

This Article is brought to you for free and open access by the Communication at Digital Commons @ Otterbein. It has been accepted for inclusion in Communications Faculty Scholarship by an authorized administrator of Digital Commons @ Otterbein. For more information, please contact digitalcommons07@otterbein.edu. 


\section{Running head: A Black Baptist Community’s Christian Media Use}

Why a Black Baptist Community Uses Christian Media: An Ethnographic Treatment of a WorkingClass Community where Christian Media Use is Shaped by Sacred Tenets, Social Influences and Personal Factors

Eric K. Jones, Ph.D.

Assistant Professor of Communication

Otterbein University

Communication Department

1 South Grove Street

Westerville, OH 43081-2006

Office: (614) 823-3388

Fax: (614) 823-3367

Submitted to the Journal of Media and Religion on December 1, 2014. Please send all correspondence

to Eric K.* Jones at ejones@otterbein.edu. (*The letter K is my middle initial only. It should not be attached to my first name which is spelled Eric - with one c.) 
Why a Black Baptist Community Uses Christian Media: An Ethnographic Treatment of a Working-

Class Community where Christian Media Use is Shaped by Sacred Tenets, Social Influences and Personal Factors

\begin{abstract}
As aspiring Christians, this African American Baptist community faces intense societal pressures. These pressures work in conjunction with the following things to help shape their continued struggle to live righteous lives - their convictions in the Baptist faith, their church and work environments and their personal and familial experiences. This ethnographic study examines how they socially construct rituals of Christian media use that help them do the following things; negotiate feelings of guilt and moral conflict, prepare for life's difficult challenges, and form meaningful social bonds with others. This study extends the literature on qualitative research conducted within the uses and gratifications tradition. It also adds to the scant amount of research that has been conducted on the Black Christian media audience. The results of this study contain ethnographic descriptions of what motivates this community to use Christian media during their struggle to become devout followers of the Baptist Faith.
\end{abstract}


Introduction

The Baptist church has been a strong presence in the African American community for almost 300 years. Enthusiastic sermons, emotional worship rituals, and self contained congregations are some of the reasons that many Blacks have historically gravitated to the Baptist denomination (Banks, 1972). Today, the largest and oldest African American Baptist group in America is comprised of 5 million members ${ }^{\mathrm{i}}$. Such a large membership in this group indicates how widespread the denomination has become. As these members struggle daily to become devout followers of their faith, they have shown a rich cultural background that gives rise to many complex motives for Christian media use.

This Christian media use has become an extremely popular trend in recent times. According to a report from the Barna Group (2002), 141 million adults used Christian media in the month prior to the administration of their survey. This was 9 million more than the number of adults who actually attended a church service during that same time period. 33 percent of adults who were surveyed in this report claimed to have read a Christian book other than the bible in the previous month. The Barna group study also estimated a total of 109 million radio listeners of religious programming and a total of 90 million television viewers of religious programming. Radio listeners in particular were characterized as being older, downscale, Black, protestant and politically conservative. This is partly supported by a Pew Research Center (2001) report showing that $42 \%$ of African Americans said they occasionally or routinely get information from religious radio or TV shows. Ample evidence has also shown that Christians are incorporating more on-line content into their media use activity. A report in 2008 showed that $31 \%$ of born-again Christians claimed they downloaded a podcast containing a sermon (Barna, 2008). The same report also indicated that $23 \%$ of evangelicals had a personal webpage or homepage on a social networking site. This large media audience is supplied by a growing number of religious media fare producers. According to Blake (2005), the Christian media industry has grown to include six national television networks and more than 2,000 religious radio stations not to mention an expanding market of Christian books and music. These trends are a sign that Christians are more actively struggling to find opportunities to engage in religious media use within the context of their daily lives. 
The daily lives of African American Baptists reveal a rich cultural background giving rise to many different motives to use Christian media. Generally, scholars have studied the motives of media use within the uses and gratifications (U\&G) framework (Blumler and Katz, 1974). Ableman's (1987) work has effectively connected this study of motives to the religious audience. Many studies conducted with the uses and gratifications framework have effectively utilized qualitative approaches. In his critical review of U\&G research, Ruggeiro (2000) identified a need to incorporate more naturalistic research methods into this line of studies. "Thus, communication researchers should be encouraged to employ $U \& G$ more frequently in conjunction with qualitative methodologies in a holistic approach" (p.24). One of the very first studies conducted with a U\&G framework utilized indepth interviews to examine the motives of women who listened to radio soap operas (Hertzog, 1942). More qualitative studies within this approach began to appear in the mid 80's with Bourgault's (1985) ethnography of Protestant viewers and Lemish's (1985) work describing the motives of soap opera viewing among college students. Massey (1995) used a qualitative approach to examine student diaries of media use during an earthquake disaster. More recent studies of U\& G have utilized a number of different qualitative approaches to study the modern day media audience. Richardson (2003) used a qualitative case study method to study why people visit an online discussion group devoted to the subject of Agnosticism. Drumheller (2005) used focus groups and rhetorical analysis of fantasy themes to study the millennial generations' religious media use activity. Urista, Dong and Day (2009) studied the motives of young adults who use Myspace and Facebook with focus group discussions and grounded theory methodology. This study extends the tradition of qualitative approaches in $U \& G$ research by focusing on an ethnographic treatment of a community of AfricanAmerican Baptists. The ethnographic approach is justified for this study because other scholars have used it to effectively describe television viewing within the "tavern culture" (May, 1999) and communication practices among inner city youth culture (Novek, 1995). Newhagen and Rafaeli (1996) have supported these kinds of methods by suggesting that scholars should examine audiences on a cultural and societal level in order to offer a significant contribution to communication research. It is also important to note that this study adds to the small amount of scholarly treatment examining the African American religious audience. Some notable exceptions include Frederick's (2003) rich 
ethnographic description of the culture of African American Christian women in the southeastern U.S. and Gooch's (1996) work describing the use of gospel rap in black religious communities. Other researchers have focused on Black Christian men - an audience that goes virtually unnoticed in communication scholarship. Boyd's (2007) work on the complexities of African American Christian men and their anxieties of race, gender and sexuality within the modern Black Church is a good example and Frederick's (2005) study examining the communicative strategies of Black Gay Christian men in traditional church settings is another valuable contribution.

\section{Method}

This ethnographic study was conducted within a predominantly African American Baptist church in a mid-sized city in southeastern Pennsylvania. Over roughly a three month period, 21 in depth interviews were conducted with church members and a separate interview was conducted with the senior pastor (Kvale, 1996). 25 hours of direct observation was conducted of worship services, church meetings, bible study sessions and media use sessions at one person's home and a women's fellowship group meeting (Lofland and Lofland, 1995). Document analysis was conducted of church literature including church hymnals, church flyers, and programs of worship services (Creswell, 1994). I wrote memos to record notes after all of the observational sessions (Sanjek, 1990). All interviews were recorded and transcribed. A questionnaire was distributed to each interviewee in order to document their ethnicity, their gender, and their age among other things. Thick description (Gertz, 1973) of the church's environment was conducted including the city, the church and the social environment of the congregation to ensure others could compare (or transfer) this subculture to other similar contexts (Lincoln and Guba, 1995). Results were generated by looking for common themes that began to emerge from the qualitative data that was gathered (Fetterman, 1989). I confirmed my conclusions and interpretations of this community by conducting member checks, triangulating data from three different sources (the interviews, the observations and the church documents) and soliciting peer review from other researchers (Patton, 1990).

It is important for this study that I mention that I am African American and I was raised in a family with a strong Christian influence. I am currently in the process of building my own personal 
relationship with Jesus Christ. My first memories of religious experiences are rooted in a small African American Methodist church. My mother used to take my two older brothers and me to church when we were little kids. Later as a teenager, I followed my mother's example and became a Baptist. I was baptized in the church where I conducted this study. I was once an active member of this church's youth group and its young adult choir. After I entered high school and college, I stopped attending church regularly for years. As I came back to this church environment, I had to get reacquainted with many of the members that I knew from attending when I was a teenager. Hundreds of members who joined the church during my absence did not know me at the time I began this study. So I needed some help regaining entry into this research context to earn the trust of this community. My mother, who has been a member for 27 years and the church's senior pastor who had stayed in contact during my years away from the church were instrumental in helping me gain initial access.

It is also important for this study that I mention that I believe in social constructionism. In particular, my view of reality is one in which knowledge is created and not discovered (Schwandt, 1994). In concert with this belief, I will examine how this community constructs media use within the context of many different social and cultural elements that exist within their daily lives. I also believe in the existence of multiple realities. As Carey and Kreiling (1974) have argued in their criticism of uses and gratification studies, scholars who operate within the $U \& G$ research tradition should account for many different perspectives (or realities) in their research. I intend to describe the multiple perspectives that exist within this community through the observations, the interviews and the documents examined in this study.

One of the strategies I used to accomplish this pursuit of multiple realities (or perspectives) was purposeful sampling (Miles and Huberman, 1994). I recruited respondents in a way that I could interview people of different ages, income levels, and ethnicity. For instance, in order to get a good cross section of men and women, I recruited members from the women's fellowship group and the church deacon board. In order to get a good cross section of age, I recruited members from the senior choir, and the young adult choir. The table below illustrates the questions I wrote on the questionnaire and the variety of responses I received from the members. 
Table 1

Questionnaire Responses from Interviewees

\begin{tabular}{|c|c|}
\hline Question & Responses per Item \\
\hline What is your ethnic identity? & $\begin{array}{l}\text { African Americans - 19, (Other) Native American, Italian \& } \\
\text { African American - 1, White American - } 1\end{array}$ \\
\hline What is your gender? & Women - 14, Men - 7 \\
\hline In what age group are you? & $\begin{array}{l}(19-24 \text { years })-0,(25-34 \text { years })-4,(35-44 \text { years })-4,(45-54 \\
\text { years })-8,(55-64 \text { years })-5,(65 \text { or over })-0\end{array}$ \\
\hline What is your current marital & single -2 , married -8 , widowed -1 , divorced -9 , separated -1 \\
\hline
\end{tabular}

How many years of education have you completed?

What is your total yearly household income? some high school - 1, graduated high school -8 , some college 5 , graduated college -5 , some graduate school -1 , master's degree - 0, Ph.D. conferred - 1

$(\$ 10,000-\$ 14,999)-2,(\$ 15,000-\$ 24,999)-3,(\$ 25,000-$ $\$ 49,999)-10,(\$ 50,000-$ up $)-5$

After a few interviews and observations, I started changing my method in order to adjust to what I was seeing in the field (Lincoln and Guba, 1985). A number of respondents during my first set of interviews indicated the importance of biblical referencing when viewing televangelist sermons. This led me to add a question about bible reading activity in my interview and to add a question about it on my questionnaire. Through my observations of choir rehearsals and interviews it became clear to me that people who were more involved in church activities outside of Sunday service, had more 
specific comments and richer descriptions of their religious media use. A question asking them to list all of their church activities was subsequently added to my interview and questionnaire. With respect to my observation strategies, I frequently had to change my observational stance from silent observer to participant observer. The research setting of this church dictated that I actively participated in sacred rituals like prayer and singing (Jorgensen, 1989). I made a judgment call in the field where I had to consider the ramifications of not participating. I concluded that not participating in these rituals would have distanced me considerably from this community.

\section{The Town of Midview}

The town of Midview is a medium sized city located in the farmlands of southeastern Pennsylvania. It can best be described as a place that doesn't lend itself to extremist ideas. Midview is a fictitious name I am using to preserve the confidentiality of my respondents. In order to understand why I chose the name of Midview, it is important to consider the meaning behind the terms "Mid" and "view". Mid is the root word for middle as in the phrase "middle of the road". I wanted to use this word because it closely resembles the heart of what it means to be a conservative thinker. The word view is another word for perspective. I wanted to use this word because I wanted to describe the predominant political and social perspective of this town. So the name Midview can be translated into the phrase "conservative perspective". This is a phrase that I think adequately summarizes what many perceive to be the dominant belief system of this town. They see it as a place where conservative values are upheld to keep long standing beliefs and traditions in existence.

The conservative values of hard work and discipline are considered staples of this community. The Amish and Mennonite communities are the embodiment of such values. They represent one of the main reasons that many consider this a conservative place. Tourism brochures routinely feature their families working on rich farmland, riding horses and buggies and wearing plain black and white clothing. Indeed these unique communities help paint this area as one with a rich background of customs and heritage. These customs are most noticeable when one visits the markets where Amish farmers sell their produce and baked goods. Even more indicative of their unique image is the way in which strict religious practices are embedded in their daily lives. 
This religious way of life for the Amish is complemented by a strong religious presence in Midview. According to the religion section in the local newspaper, there are over 200 places of worship in this community, not including Synagogues and Mosques. The church denominations listed include Anglican, Baptist, Mennonite, Lutheran, Pentecostal, Presbyterian, Roman Catholic, Methodist and many others. By far, most religious organizations practice some form of Christianity. The diverse offering of religious denominations has become a normal part of this city's cultural landscape.

An equally important part of this city's cultural landscape is its physical appearance. In many ways it is directly the opposite of what you might expect for a city located in the middle of hundreds of acres of open farmland. Contrarily, Midview has plenty of homes with virtually no open space between them at all. In many areas, blocks of connected row houses line the streets and they very rarely contain front yards. More often than not, small front porches and sidewalks are the only thing separating these houses from the streets of their location. Within each connected row home section, the border of each house is demarcated by different colors. From a helicopter's vantage point, these row homes would look like an assortment of small bright colored cubes with windows and roofs on top. The close proximity of these houses and buildings in many ways resembles that of a larger city where businesses, homes, and schools are all tightly packed together. At certain times in this town, the activities of a normal day create a community of people busily going about their daily routines.

A large percentage of these busy people make up the city's working class community. On average, a typical household in this area earns just fewer than 40-thousand dollars a yearii . But recently, this group has had to face some serious obstacles. Among them are the high levels of unemployment stemming from the economic recession of 2008. Estimates from the Pennsylvania Department of Labor and Industry indicate that the unemployment rate in this area increased to 8 percent $^{\mathrm{iii}}$ - which is the highest it has been in years. Another obstacle is the city's crime rate. According to the FBI, the city of Midview posted 534 incidents of violent crime during the year of 2008. That ranks $8^{\text {th }}$ out of 897 municipalities listed in the state of Pennsylvania ${ }^{\text {iv }}$. The problems that plague this community create a sense of anxiety, doubt and fear among many of its residents.

A lot of these negative feelings are exhibited by this community's diverse array of minority group residents. People from other towns often assume that the residents of Midview mirror the 
mostly White Mennonites and Amish who adorn the tourist brochures marketing the area. Nothing could be further from the truth as this area's residential population contains a solid, but far from overwhelming white majority. According to the census bureau, a total of 55,439 residents live in the city of Midview ${ }^{\mathrm{v}}$. Whites comprise the majority of the population at a little over 66 percent. By far, the largest minority group in the city is the Hispanic community who comprise roughly half the percentage of Whites at 33 percent. The third largest minority group is the African American community who comprise 15.3 percent of the residential make-up. Among the other minority groups with substantially lower rates of residency in Midview are Native Americans, Asian Americans, Native Hawaiian and other Pacific Islanders and a hodgepodge of other races.

The largest minority group in Midview has left a unique imprint on the city's cultural setting. Many members of the Hispanic community exhibit pockets of cultural influence throughout the city's many neighborhoods. In various sections of the city, the existence of a strong Hispanic culture is evident. Most Hispanics in this area are comprised of Puerto Rican, Cuban, Colombian or a complex mixture of Latino nationalities. Most are American citizens with strong family ties to New York City, Philadelphia, Puerto Rico, or other neighboring mid-sized cities in Pennsylvania. In many ways they exhibit a strong sense of Latino pride. For example, many of their homes and automobiles contain Puerto Rican flags placed openly on display. Low riding cars can often be heard playing Spanish music on loud booming sound systems. Every main grocery store chain in Midview sells food products that commodify Hispanic culture to accommodate this community as well as others. A dwindling number of restaurants and corner stores owned by Hispanics remain in existence but the recession and other factors have forced many of these places out of business. Many have learned to speak English, but occasionally have adopted a hybrid version of Spanish and English as they must adjust between communicating with older family members who never quite learned to speak English and communicating in most other situations where they must assimilate into everyday life.

African-Americans have a strong presence in this town as well. A few select barber shops and hair salons are the cornerstones of Black culture in Midview. The hairstyles are as various as the personalities of the people who wear them. African American women and men display hair styles that are consistent with their identity, their fashion sense, their economic means, and their social group's 
acceptance. Inside the hair salons and barbershops of Midview's African American community, are the rich discussions and interactions that deal with a discursive mixture of current events, popular culture, school, commodities, sports, politics, work, relationships and religion. Rap music, R\&B and some contemporary gospel music recorded on mixed CD's are as prevalent as Spanish music in loud booming car systems. Interwoven among the dialogue and expressions of African Americans is the frequent evocation of faith. Even in contexts outside of a formal church or religious environment, you'll hear people often mention their faith in God as a means to get them through their daily routine. Those who are deeply religious will attribute all fortunate things to God's perfect plan. For instance, when Barack Obama was elected president, many members in the community frequently shouted aphorisms like "That was God's Work" and "Hallelujah" and "Thank You Jesus". Those who aren't as religious, still evoke their faith in God in more subtle ways. Those who get themselves out of a difficult situation will sometimes make a simple statement like "I'm blessed". In these cases, God's presence is almost used in the same way a self-help theme is used - as a means to focus on one's life with a positive outlook.

In Midview, Hispanics, African Americans and Whites have had a distinct influence on each other through interracial relationships. Despite the fact that a lot of members within each group prefer to have children with members of their own race, more and more interracial children are being born in Midview (Rockquemore and Laszloffy, 2005). Hispanics, African Americans and some Whites have strong community roots in the southeast section of the city where they attended the same schools and dated each other. These relationships either resulted in interracial marriages, interracial relationships resulting in teenage pregnancy, divorced or single mothers who head their own households or interracial couples living together. These situations have produced a lot of mulatto children that create life-long familial connections and relationships between Blacks, Whites and Hispanics. This creates a complex mix of style, food, dress, expression and values that these children adopt from all of their ethnic backgrounds.

Unlike these aspects of mixed cultural influence, religion in Midview has been much slower to integrate different ethnic groups although some encouraging signs exist. Many Hispanics in Midview have traditionally gravitated to either Roman Catholic churches or their own Christian 
congregations. Blacks on the other hand are predominantly Christian but a modest number have converted to Islam. At least five predominantly African American churches can be found in Midview and two of them are of the Baptist tradition.

The Serenity Baptist Church

The "Serenity" Baptist Church in Midview, Pennsylvania is a place of worship with a growing membership. The name Serenity is a fictitious name I'm using to preserve the confidentiality of my respondents. I chose the name in part because of the formal "welcome to visitors" ritual that occurs at each church service. Although many other churches do this routinely, Serenity recruits its young church members to invite new guests to stand up and introduce themselves to the rest of the congregation. As a former member, I can remember doing this when I first joined Serenity as a teenager. I was around 14-15 years old. On that day, I walked up to the microphone to give the greeting while feeling nervous and anxious to speak in front of the entire congregation. I said something to the following effect; "If there are any visitors in the church this morning, please stand and state your name and where you are from". Guests in attendance stood and introduced themselves to the rest of the congregation. At the end and during the introductions, shouts of warm-hearted welcome and affirmation rang out from the other members of the church. "A-men”! "Welcome”! Still nervous and anxious, I proceeded to give the following greeting to the visitors after they finished their introductions. "On behalf of the pastor and all of the members of the Serenity Baptist church, we welcome you". What followed was audience applause, more shouts of a-men and encouragement for the visitors to become new members. This ritual has been carried out ever since the Serenity Baptist church was first established.

When Serenity first began in the early 1980's it was located on the first floor of an apartment complex. The church was located in a spacious room and members sat in an arrangement of fold-up chairs with an aisle down the middle. During that time, the church only had 1 worship ceremony a week. Since then, the church has moved twice do to the growth of its congregation. Now, the membership has swelled to approximately 800 members, not to mention a steady influx of visitors that come to each church service. 
The pastor of the church is the leading force behind its growth. He is revered among the church members with deference and respect. For this reason, I will call him Pastor "Reverence". Under his visionary leadership, the church is now worshipping in a relatively new state of the art building that contains a modern sanctuary with an adjacent community center. He is a tall man, about 6 feet 2 inches tall. He wears glasses and he speaks with clear diction and intelligence. There are many signs that he has gained the trust and loyalty of this congregation. A good example is the way they respond to his leadership and vision. When the church was in the process of raising money for their new building, he would set forth his vision by having the congregation recite the church theme he had put in place for the project.

Pastor Reverence - "We do have a theme here at Serenity. Where is it found please"?

Congregation (In Unison) - "Psalms 127, verse 1".

Pastor Reverence - "And with a little more enthusiasm and confidence. Would you recite the theme for us please"?

Congregation (In unison with more volume) - "Except the Lord build the house, they labour in vain that build it: except the Lord keep the city, the watchman waketh but in vain."

Pastor Reverence - "Thank You. We have a sub-theme and what is that please"?

Congregation - "This is the year; No Excuses"!

Since then, the church has continually forged partnerships with other community organizations under his visionary leadership.

During the annual Women's Day ceremony, the church pays its respect to the dedicated women who serve as the backbone of its operation. Indeed, women serve as ministers, trustees, ushers, Sunday school teachers, and other key posts throughout the entire church structure. The tone of the women's day ceremony can be reflected on many different levels. The women's day choir marched into the ceremony with white dresses and purple scarves. These outfits reflected the chosen colors of the ceremony which changes every year. The programs that were distributed before the ceremony were printed on light purple paper. This was a noticeable change from the yellow programs that are distributed every Sunday during regular services. A biblical verse from the book of Proverbs was printed on the cover as the selected biblical verse for the ceremony.

"Every wise woman builds her house, but the foolish plucketh it down". Proverbs 14:11 
The theme of the women's day ceremony was located under the scriptural verse in bold black letters. "Women of Serenity Baptist Church building a firm foundation - This is the year - No Excuses"! As mentioned earlier, the town of Midview contains a very diverse population of residents. To a certain extent, Serenity's congregation is a reflection of this diversity. Although the church leadership, the rituals of worship, and the music are firmly rooted in African American influence, a small but loyal percentage of the congregation classify themselves as mulattos, Hispanics, or Whites. Many of them have joined Serenity because they like the worship experience that allows them to be more expressive and free about their conviction in Jesus Christ. One of the few White women who attend Serenity had this to say about her experience as a loyal member of the congregation.

"Because I'm one of very few Caucasians in a primarily African American church. But I have thought over the years why do I go there? It's like the Lord has kept me there for a reason. I think one reason is the type of worship and the type of spirituality. Not to make a general statement. It has been my experience frequently that there's no inhibitions in terms of praise that I happen to be praising around a lot of African American people. For instance, if I go to a church that's predominantly all White frequently I have friends like this. They're just a little more reserved afraid to say anything or that kind of thing where I know at (Serenity) people just are not like that. They're just so real about what God has done in their life. There's no inhibitions there".

This woman and other members of the congregation who come from different ethnic backgrounds help challenge Serenity to become a church that is true to its history, but inclusive to members coming from other ethnicities and religious denominations. Indeed, a small number of Whites, mulattos, and Hispanics have become ministers, church choir members, and deacons at Serenity.

The Serenity Baptist Church does not exist in a bubble. The Church often joins other community organizations in Midview to participate in peaceful protests, to serve on community panel discussions, and to partner with other church congregations. For instance, some members of the local branch of the NAACP distributed a flyer at one church meeting encouraging members to take part in exposing the discriminatory hiring practices of a local police chief. At the top of the page, in black bold face letters the call to action read; "What have you done today - to eliminate DISCRIMINATION???". These concerns of discrimination were exacerbated when a local branch of the $\mathrm{Ku}$ Klux Klan publicly announced plans to hold a rally in downtown Midview. At that point, the church worked with local businesses, churches, and politicians to organize a peaceful protest to the Klan march. After the intense pressure mounted from the publicity of the march in the local media, the 
Klan later called off the march. The members of Serenity and the other community organizations followed through with their plans for a peaceful protest by having a community picnic at the local park where all members were welcome to join an informal ceremony where everyone prayed for peaceful existence among all residents in Midview. This is an example of how the members of Serenity must constantly struggle between things that challenge their faith, (i.e. racism, materialism, sex, and violence) and their desire to maintain what they call a righteous lifestyle. With all of these serious concerns facing this community, a couple of questions come to mind? What sacred beliefs and traditions of the Baptist faith help them maintain their imperfect and difficult struggles to follow the righteous path? How will they use religious media as they live in this ever changing world where so many threats challenge their sense of security?

The Customs, Rituals and Beliefs of Serenity Baptist Church In joining the Serenity Baptist Church, new members are encouraged to do many things. But one of the most reliable ways to gain authentic acceptance and entry into this church community is through the act of testifying. Serenity operates in accordance with many other churches in welcoming the act of testifying. The members of Serenity take a tremendous amount of pride in cultivating a close-knit community. A key to maintaining this closeness is an expectation that members and visitors talk openly about what God has done for them. More specifically, the act of testifying requires members to speak openly about how their experience has led them to pursue membership at Serenity and a personal relationship with Jesus Christ. At Serenity, the act of testifying represents a process that differs within each member or visitor. Some members frequently testify while others are more reticent. For those who are reticent, leaders and more experienced members of the church will take certain steps to encourage and affirm the personal stories that they share with others.

Many testimonies are considered powerful at Serenity because of the effect that they can have on other people. Some powerful social consequences that indicate a welcomed presence can result. One example of this is that other members of the church will begin to exhibit more open communication with that person. It is widely understood that the disclosure of this information can be very difficult for some members. Especially for those who are new to the environment, and those who 
are going through very delicate situations. If the testimony is perceived as being sincere, heart-felt, and timely, members will respond by showing different forms of affirmation. They may introduce themselves, they may exhibit sympathy, or they may respond by a pat on the back or a hug. Other effects of testifying may not be as overt. Sometimes the effect of a testimony may not surface until months later. In one interview, a gentleman made the following comments about the significance of testifying at Serenity:

"Because whenever you go through something, and you know the Lord brought you out of it. Now you keep that to yourself. If you keep that to yourself, it's wrong! Okay, because someone might be going through that same thing that you came out of. And it's important to let people know about it. Because if the Lord brought him through it, he can bring me through it. All they have to do, is a lot of people have, they just need that confirmation. That they can trust in the Lord, and he will bring them out".

Giving sincere testimony at Serenity, is like a "ticket" into the hearts and minds of the rest of the congregation.

Another important requirement for the members of Serenity Baptist church to engage in is the reading of the Bible. This community relies on the Bible as the ultimate authority of God's word. There is a lot of emphasis placed on both understanding it and maintaining its authenticity. One indication that the members of this community consider it important to understand the scriptures is the popular use of the NIV (New International Version) of the Bible. Many members of Serenity consider its language to be much more accessible than the King James version.

"With the NIV version of the Bible, I think is most helpful. I found that I understood and learned and retained things so much better with reading the New International Version. The King James version just really went over my head because I think I got stuck on the thee, thou goist and all that type of English. Where if it's written the way you and I talk, it's much more easily understood".

The need for clarity among some members of Serenity is contradicted by other members who prefer to stay as close to the original version of the Bible as possible. Many reject the accessible language of the NIV because they say the authenticity of its text gets compromised during the translation. One gentleman I spoke to expressed strong disapproval of the NIV.

"I even got a problem with some versions of the Bible. I use the King James and you can go over it. It's about the NIV they're using now. And it's the New International Version. I'm afraid I'm calling it the New International Perversion, because it distorts the word of God"'

After he said this, he showed me an example of a scriptural reference that exists in the King James version, but does not exist in the NIV version. He asked me to look up Mark, chapter 9, verse 44 in the 
King James bible. I looked it up and the scripture read "Where THEIR WORM DIETH NOT, AND THE FIRE IS NOT QUENCHED”. The he asked me to look up the same scriptural reference in the NIV bible. I searched for it and I couldn't find it. It wasn't in the NIV. The whole verse was missing. For him, that was inexcusable. So it is clear that there are different preferences in this community when it comes to consulting versions of the Bible. But one thing is also clear, seeking to understand the bible is extremely important at Serenity because it is seen as one of the primary ways to understand and communicate with God.

The most distinctive religious tradition associated with the Baptist church is the ceremony of Baptism. According to the Merriam-Webster dictionary, the word stems from the Greek word baptizein, which means to dip. At Serenity, a legitimate baptism is one that is defined by such dipping, or full immersion. In other words, a person is not considered fully baptized at Serenity unless they undergo the complete submergence in water during the ceremony. Symbolically, the act of baptizing represents the death of sin in a person's life and their resurrection to a new and holy life. Pastor Reverence comments on this symbolism more fully:

"We believe the scriptures teach. And Christian Baptism is the immersion. And that's what's important to Baptists. We baptize by immersion. In other words, we bury the person under water because we believe that's what the scriptures reveal to us. ... With its effect in our death to sin and the idea of going in the water is the dead. So if something is dead, you bury it. So we bury it as Christ was buried. Us in water. Him in the grave. Resurrection when we come up out of water it symbolizes His resurrection. And Paul says in Romans chapter 6, you are to walk in newness of life".

The baptism ceremony of a new member is significant because it means that the person is now a legitimate member of the church and is now considered "saved" or "born again". The practice of baptism at Serenity is different in some respects than the practice of other churches that perform this ritual. At Serenity, a person must profess their belief in Christ as their savior before they are baptized in water. Other churches believe that the act of baptism actually saves the person. Pastor Reverence maintains that the act of baptism is an indication that you have been saved, but it is not the definitive act of being saved. Another important difference lies within the way that baptism ceremonies are performed. In some churches, baptism is conducted by pouring or sprinkling water over a new member during the ceremony or touching the forehead of the new member with a wet finger. By stressing the requirement of a believer prior to the ceremony of baptism and the full immersion of the 
new member in water, Serenity identifies itself with some of the more strict churches when it comes to the rules of baptism.

\section{"Give it to God!" The Process of Adjusting to the Baptist Faith}

In this community, it's clear that the act of watching a televangelist program or listening to a gospel song doesn't happen because the sermon or the music is so provocative that people are drawn into the message. It happens because of what they have experienced before they even turn on a television, listen to a radio, or download a podcast. Religious media use is often the by-product of many different factors that exist within the lifestyle of a person who has dedicated themselves to becoming a born-again Christian. The people at Serenity often speak very vividly and emotionally about these cathartic moments in their lives. One lady I spoke to revealed how she felt when she finally decided to make this commitment.

"I started going to church because I knew that I wasn't going to find relief unless I turned to God. The only way I was going - Nothin' in the street. No other person. And I really didn't have a mother and father to turn to you know. So I had to go to church. Cause I knew I would find what I needed in my heart, in listenin' to the sermon".

In many cases, people couldn't talk to me about their media use until they revealed what called them to a Christian lifestyle first. In their minds, much of their media use activity was significantly less important. Heart wrenching stories about divorce, death, and illness were some of the life-altering events that led people to this church. One gentleman told me he decided to turn his life around after his mother died in his arms. Another man I spoke to told me he decided to start coming to church to help him deal with the pain of his father committing suicide when he was young. There were as many different reasons for making this commitment as there were people. Many members of this community told me they began to experience a lot of obstacles and self-doubt during this process.

The path to righteous living for the members of Serenity is fraught with lots of personal challenges and ambivalence to this new way of living. People in this community refer to this process as developing a personal relationship with Christ. After speaking with and observing members who were at various stages of this relationship, they began to reveal some intense moments of struggle with their faith. One of the most vivid examples of this occurred during a bible study session where one of the church deacons was engaging in a dialogue with a man in attendance who had just joined the 
church. In the following exchange, he exhibits some profound frustration about his employment situation.

Bible Study Attendee (BSA:

"I ain't been back to work for a long time. I used to work at (a local factory) and I broke my arm by accident. Now I can't get other work because I'm no good to anybody. And I have this anger that is built up inside of me. My medical bills are high, and I can't make ends meet. I just got a lot of anger"!

Deacon:

"Brotha, it's because you're not lettin' go. Yea you got all that anger inside of you. But you goin' keep it there until you open yourself up to God".

BSA:

"I read my Bible all the time. But I still feel anger. And I can't keep my mind off of all the stuff I been through".

Deacon:

You're not givin' it to God! You gotta' put it in God's hands and he will take all that stuff out of you. There is nothing he can't do brotha. But right now, you're tryin' to handle it all by your self. You can't! We can't do it by ourselves! We have to give it to Him and he will take care of all of the rest"!

This exchange illustrates the most profound struggle that many members of Serenity face on a daily basis. This is the struggle to relinquish self-control. In the above exchange, the emotion in the man's voice was intense, and the frustration was palpable. After that exchange, he sat quiet for the rest of the bible study session. I didn't know if he decided to heed the message of surrender or not. But he was clearly at the point that many members of this community get when they're confronted with a principle or scripture that they have a hard time adhering to in life - the point where their true belief in God gets challenged. Indeed learning how to "Give it to God" becomes the inspiration for a lot of prayer. For instance, prayers often begin or end with the following phrase. "God, please give me the wisdom, the patience, to deal with this situation".

Other instances of personal struggle come from members who are in the process of leaving old habits behind. Members at Serenity often talked about how hard it was to make the transition to a Christian life. For one woman, it was a gradual process in which she initiated some steps to becoming a devout Christian, but she would occasionally revert back to hanging out with her old friends.

"Then when I started going to church, I was not active. You know dipping and dapping going to church. Stop going - dipping and dapping and I joined. I started going to church and then I started getting active one year. At that time, I was drinking you know hangin' out drinkin'. Going to happy hour and stuff like that. But when I got a key (to the church) and I'm dealin with kids in the church. I was like wait a minute. This just doesn't seem right. So 
little by little growing, growing more you know, I stopped drinkin', stopped hangin' out. Started tryin' to make changes within myself".

Her comments exemplify a continuous challenge among many of the members at Serenity where they feel like they are "caught in the middle". On the one hand, they have their social life and their friends and they want to remain loyal to them. On the other hand, they have this newly found faith that is pulling them in the opposite direction. This is a gradual and complicated process where the members of Serenity have to negotiate their relationships with family, friends and acquaintances. Indeed, it becomes a delicate balance where members have to redefine their social image as they move forward toward their lives as devout Christians.

There are other members at Serenity who are definitive in their disagreements with some of the aspects of the Baptist faith. One woman I spoke to was a former Catholic and she had recently joined Serenity. One of the most difficult things for her came when she found out how members of the church viewed the status of women in relationships. She expressed some sharp criticism toward the church's view of the unequal relationship between the husband and wife.

"Those yeah some women are supposed to be a little bit more subservient. They let the man make the decisions. He's truly the head of the household and you're always here to support him. This is true I mean for those who were brought up in the Baptist faith. I was not being brought up in the Baptist faith. That may be what the difference is. Because I grew up in the Catholic faith and they don't stress that. They really don't. But as I was hearing this, I thought I don't agree with that".

This woman told me she had voiced her concerns to Pastor Reverence about this unequal relationship. She describes the disagreement as a respectful one, but she acknowledges that these kinds of religious beliefs give her some pause about the way Serenity practices the Baptist faith. Although she is generally happy with her decision to convert to the Baptist denomination, this is an example of her ambivalence in her path to spirituality.

Other members of Serenity are disappointed because they feel restrained during the worship and praise rituals. For those who come to Serenity from more regimented and controlled worship traditions (i.e. Methodist churches or Catholicism), the singing, praying and outward expressions of praise are a welcome experience. They represent a worship environment that is free of constraint. Interestingly enough, others actually find some of Serenity's worship tradition too restrictive. One 
woman explained how others reacted when she decided to shout and openly praise God at a women's

fellowship meeting.

"And that connection I felt with God would do something for me as I tried to feel the spirit the whole way. Whatever I was going through, I needed to praise Him and I didn't want to hold back. And some of the women even when they would be feeling some of these things, they didn't accept it and they would walk out of there kind of like well that wasn't me. I don't know what happened to you. You know some wouldn't come back and they would find fault with the people that were there or something. You know just because some people they just at that time they were so caught off guard. Because a lot of people are still running from it. They just don't want to hear it. I don't know whether they just don't want to get better. They don't want to try. They just kind of still want to carry that pain around with them rather than to let anyone know that they're hurting."

This woman's comments indicate how therapeutic and cathartic this kind of worship experience has been for her and she genuinely feels that others are robbing themselves if they hold their praise in. At Serenity, they call this "getting the spirit". Many members of the church community are open to this kind of expression, but others are not open to it. Indeed, there is a slight tension in this community between these two worship camps. Serenity is an open place of worship for members to "get the spirit", but it is far from the kind of experiences found in Pentecostal churches where members speak in tongues. More often then not, you'll find more moderate levels of spiritual exuberance within prayer, within singing, and within the responses to the pastor's sermon.

\section{Religious Media Use at Serenity}

The members of Serenity have very idiosyncratic habits of media consumption. Even among all of their differences, I saw few recurring characteristics that came out of the qualitative data with regard to religious media use activity. The following items represent the most common themes about media use that emerged from the interviews, observations and documents I examined in this community.

The importance of time and access proved to be a very critical precursor to religious media use among the members of Serenity. Among this working class community, media use was a struggle because many people were trying to balance so many responsibilities. Between family, work, school and church obligations, religious media use activity was situated within pockets of convenient opportunity where members would either use media during periods of downtime, use media as background programming while performing other duties, use media individually, or use media during 
social gatherings with others. In addition, some of the members I spoke to had to deal with access issues. A few of the older members didn't have basic cable, so their choices were somewhat limited. Others had cable, but experienced some programming changes where some televangelist shows were switched to a different time and they went through a period of uncertainty as to when the programs aired. At the time of this study, some members of this community were connected to the internet and used it actively to listen to sermons, download gospel music, and participate in social media sites. Other members either had access to an internet connection and used it sparingly, or did not have internet access at all.

Biblical referencing proved to be important for the members who frequently consumed televangelism programs. The members I spoke to who listened to or watched televangelism expressed a lot of interest in ministers who openly and accurately referred to biblical scripture during their programs. With such an important emphasis being placed on the bible in this community, many members showed a clear preference for preachers who rooted their messages in biblical scripture. In particular, there was a big concern among the members of Serenity to watch for distorted biblical teaching.

"If it stays within the word of God and in the right context I can go along with it. If it's out of - if there's something that's twisted then I don't want it. You read the Word (The Bible). And you know the words in it. The Word is to edify us and lift us up".

Some of the most respected televangelists among this community were popular because of this quality. Some examples include Dr. Tony Evans, Charles Stanley, Joyce Meyer, Bishop Eddie Long, Bishop T.D. Jakes, Juanita Bynum and John Hagee. One particular criticism about distorted biblical scripture at Serenity was directed at the popular "Prosperity Preacher" movement. Exemplified by TV ministers like Leroy Thompson and Kenneth Copeland, the prosperity message emphasizes the scriptural passages that deal with wealth and materialism. Many members exhibited a strong skepticism toward this message.

"I believe that a person's relationship with God is very personal and whatever Almighty God intends for a person to have, nobody can block that. Now that's what I believe. They make you feel like something's wrong with you if you don't have the money and all of that. And a lot of them have got off so much into that. They've forgotten the main focus of why the Bible is here in the first place or why Jesus came. And that was to save souls". 
Many of the members at Serenity who communicated these sentiments were avid bible readers. They tended to be ministers, deacons, or other members of the congregation who routinely dealt with scripture in their involvement of church activities. In these instances, they carried their biblical knowledge and Christian sensibilities into their media use activity.

The members of Serenity also showed an overwhelming preference for gospel music by Black artists. With a few minor exceptions, most members of this community repeatedly listed gospel singers and groups that fit into the genre of exuberant, uplifting and spiritual Black church music. Some tension does exist between the members of Serenity that prefer older, more traditional artists that have historically been producing gospel music for years and the members of Serenity that prefer the newer and more contemporary artists. Most, but not all of this tension exists along the lines of age. Some of the older members told me that they gravitate to gospel artists like Albertina Walker, Mahalia Jackson, James Cleveland, Edwin Hawkins and Shirley Ceasar. One of the women had some reservations about some of the contemporary gospel music that gets mainstream acceptance from secular urban contemporary radio formats:

"I mean they played Kirk Franklin in a bar. So now well it's supposed to be a religious beat. Nothing that doesn't sing. They don't hear the words. All they hear is the beat of the music. So that's why I think rap gospel to me is not doing it. Because they're going to hear the beat of the music and really not the message that you're sending across".

In her mind, gospel music should be pure and its lyrics and message should be front and center to the audience. On the other hand, younger members readily accepted the popular and mainstream artists. The members of the young adult choir mentioned their preference for more contemporary artists like Mary Mary, Fred Hammond, Donnie McClurkin, Yolanda Adams and the aforementioned Kirk Franklin. For them, music that speaks to their style is positive because it spreads the message to others who may not normally listen to gospel music.

Many members of this community also like televangelist programs where they can relate to and identify with the featured ministers. The reasons that people felt that they could relate varied from the perception that these ministers were honest, direct and authentic in their appearance to the perception that these ministers were passionate, informative and understandable. One of the most popular words members used to describe the appeal of televangelists was "real". This woman revealed to me during our interview why she liked watching Joyce Meyer: 
"I love this woman because I can relate to this. I can't have nobody, because in my flesh, I can be rebellious. You know and with Joyce, she speaks to me and normally, I don't get into White preachers. Number one is that she doesn't preach at you and she uses her own life experience. She does not come off like she is 'holier than thou' or she has it all together. She talks about her faults and her weaknesses and through God, how she's dealing with it. That's why I really like her. She's real".

Members also liked Bishop T.D. Jakes, Juanita Bynum, and Bishop Eddie Long for similar reasons.

The appeal of these ministers were regarded by many of the members of Serenity as valuable because they could focus on their faith outside of the church environment and they can sincerely identify with the minister or the topic they were speaking about in their message.

\section{Motives of Religious Media Use}

In most cases, the underlying motives behind religious media use stemmed from influences, events, and factors that existed within the social context of a member's daily life. Many members of Serenity indicated to me in one way or another that as they were dealing with life's challenges, they came to appreciate the use of certain religious media forms. The following motivational themes appeared from the qualitative data.

In many cases, religious media use helped many members of this church deal with feelings of moral conflict and guilt. A lot of people at Serenity showed conflicted feelings about secular entertainment. For the majority of people in this community, the use of different kinds of religious fare is in part another aspect of their struggle to live righteous Christian lives. Many people have reluctantly indicated that they often get pulled into a lot of media programming that distracts them from their pursuit of righteous living. For some, there are definitely some strong concerns about what they see in mainstream secular media. I asked one gentleman how he deals with regular programming:

"I'm not to the point yet where I can totally give up regular TV but it's a growing process. TV commercials are all filthy these days. The stuff that they show and how they take your mind off of stuff. But I can't get rid of the cable. My wife loves TV. More than I do. I do watch the sports. I would like to watch an adventure movie occasionally every now and then. I like Indiana Jones you know. I like Star Trek".

In his case, he shows some very ambivalent feelings about mainstream media. He's definitely influenced by his family and his attraction to the sports and film industry. This exhibits a common feeling among many members of Serenity where their respect for biblical principles creates moral conflicts with their consumption of programs, movies and music in popular mainstream entertainment. 
One woman I spoke to admitted watching the television sitcom Will and Grace on a regular basis. She indicated feeling guilty about watching it because the program features themes of homosexuality. Many carry these feelings with them into all of their media use activity. But some religious media programs are encouraging to members who realize they will occasionally fall off of the boat and commit an act of unrighteous behavior. One woman told me she likes how Joyce Meyer gives her permission to forgive herself for her infallibility.

“And she presents herself as someone that deals with life's ups and downs but through Christ, she's making it. And so that's the way I do it. Because every day we sin. But some Christian folks act like they got it all together. And that's certainly not me because I don't”.

For her, she gets the encouragement that she needs from Meyer's testimonies of infallibility which in turn affirms her experiences where she admits to falling short of righteous Christian living.

In other cases, religious media were used to help people form meaningful social bonds with other church members. The women's fellowship group was a collection of adult female members who conducted monthly meetings on Friday nights. The members in attendance would participate in an informal gathering where they would often give testimony, pray, and share their life experiences. They would also watch televangelism programs on DVD during their meeting. With access to a large 48 inch television, they sat in the downstairs lobby of the church and watched sermons by any of a number of popular ministers. Some of their favorites included Juanita Bynum and Bishop T.D. Jakes. I attended one of these meetings and participated with these women in their rituals of prayer and testimonies. The preacher we watched that night was Bishop Eddie Long. His style is one with lots of exuberance, and interaction with the congregation. His sermon dealt with the temptations of sex outside of marriage. At one point, he talked about married couples cheating on each other. His comments, though not exact went something like this:

"Married church folk should be ashamed payin' for hotel rooms in order to commit adultery. That's why God put bibles in them hotel rooms. Because God is in that room"!

This part of Bishop Long's sermon drew shouts of agreement and hand clapping among the women who were in attendance that night. One of the women I interviewed told me what she valued about watching those tapes in the company of other women:

"And we would be sitting in there watching these ministers and you would see women crying. Just so many things were opened up to us and we just formed a bond. It was like you know 
all of us were going through different things. But through these tapes, we all got ministered to in one way or another".

This kind of social gathering among these members created an incubator of spirituality for these women to share their experiences. This is a place where older women mentor younger women and a social environment of acceptance and unconditional love is expressed openly and freely. One example of this occurred after we finished watching the sermon from Bishop Eddie Long. One young woman expressed her frustration and sadness when she told the other members of the group about her living situation. Her emotional plea went something like this:

"Can I say something to everyone? I just want everyone to know that I just moved out of my boyfriend's apartment today. We've been livin' together for awhile and I have two children to him. I tried to get him to clean up his act, but now I know he's not going to change. I want to turn my life around and start coming to God! (Starting to cry) I left him this morning while he was asleep and he doesn't know I've left for good. I took the kids. Now I'm scared because I don't know what to do without him".

She then slumped her shoulders and put her head in her hands and proceeded to cry more outwardly.

The other women in attendance immediately rushed over to give her hugs to comfort and reassure her.

This is one example of how many women at Serenity showed their desire to forge strong emotional ties with other members.

In this community, there were also lots of members who used religious media to help them prepare for what they considered challenging moments in their lives. A lot of people that I spoke to at Serenity readily acknowledged that the daily grind of their working class lifestyles became daunting at times. In other words, they exhibited a strong need to "refuel their tank". One man told me how stressful his family life became after he lost his job. During his period of recovery, he explained to me how inspirational the singer Donnie McClurkin became to him:

"Donnie McClurkin yea. Like his song 'Stand'. That's a wonderful song. I love that song. Because it's sayin' when you can't do nothing else. Just stand. When you stand for the Lord, that's when you find out exactly what he is all about. Because it says in His word that 'my power is made perfect in weakness'. When you're at your weakest, that's when you just stand for Him. When you lean on Him and you trust in Him. When you don't know where that car payment's comin' from or that rent money's comin' from, just stand. Yep. Don't sit around and worry about that now. Because I don't! I tell my wife everyday I just smile and say 'You better stop worryin about that"'.

His comments indicate how that he found peace of mind and perspective through the lyrics of that song. He mentioned to me how valuable the song was because it inspired him in the same way that a good testimony would inspire him. It represented a story that he applied in his own life. It's also 
important to note how that song addresses the Christian struggle to give up self control and surrender to God. It's an indication of how the trust in God must be complete and absolute in this community. Another aspect of this need for preparation at Serenity doesn't necessarily deal with the kind of dire circumstance of losing employment. Sometimes the purpose is to prepare for something as simple and innocuous as the church service itself. Some members of Serenity indicated to me how much sluggishness they felt before going to church on Sunday. For various reasons, attending Sunday morning service was reason in and of itself to seek help in maintaining a positive outlook. One member told me how she began to use the televangelism programs on TV to get herself ready to fully participate in the service:

“You really can't get up, put your clothes on, and come to church and start relating. You've got to prepare yourself. It's just like trying to prepare for the concert. You got to pray. Even on Sunday morning when you come to church. And a couple of times when I didn't do the preparation, I could tell the difference. I would get to church and I was like 'I need to be doing something else'. My mind was wondering. It would take me half of the service to get focused".

This was especially relevant for church members who were involved in different aspects of the church service. The members of the usher board, the choir, or the ministers had a vested interest in coming to the service prepared because their duties were integral to the completion of the service. And TV ministers like Charles Stanley, and Bishop T.D. Jakes were helpful in this regard because their programs were often aired before church services on Sunday mornings.

\section{Conclusion}

Examining this community of the Black Christian media audience through ethnography adds to the line of studies that have begun to show this audience as a diverse, complex and multifaceted one. There are many stereotypical and overly simplistic views about the African American religious community. Hopefully the description of this subculture of Baptists helps break down these misconceptions. This study is intended to be useful for members of clergy who are interested in reaching an African American audience through media, other scholars who are interested in the work of religious media audiences, and members of other religious communities who seek to learn more insight into the sacred rituals and media use activity of African American Baptists. These devout Christians show idiosyncratic preferences of religious media as a bi-product of their convictions in the 
Baptist faith, their personal and familial influences, their social networks and the sacred tenets and traditions of this church. This study described how members consumed media programming thorough pockets of convenience in their personal lives where they considered time and access, biblical referencing, and the preference of black gospel music over all other styles. The motivations of this community to consume religious programming included dealing with feelings of guilt and moral conflict, establishing meaningful social bonds with others, and preparing for challenging situations in life. The circumstances of religious media use were considered among this community to be secondary and far less significant than the cathartic, life-altering moments in which the members of this community came to the realization that they would become dedicated followers of Jesus Christ and the Baptist faith. 


\section{Acknowledgements}

To the members of the Serenity Baptist church who have and continue to inspire me to this day!

EKJ 


\section{References}

Ableman, R. (1987). Religious television uses and gratifications. Journal of Broadcasting and Electronic Media, 31(3), pp. 293-307.

Banks, W.L. (1972). The black church in the U.S.: Its origin, contribution and outlook. Chicago, Ill: The Moody Bible Institute.

Barna Group (2002, July 2). Christian mass media reach more adults with the Christian message than do churches. Retrieved July 21, 2010 from http://www.barna.org/barna-update/article/5barna-update/77-christian-mass-media-reach-more-adults-with-the-christian-message-thando-churches?christian+media.

Barna Group (2008, May 26). Barna technology study: Social networks, online entertainment and church podcasts. Retrieved July 21, 2010 from http://www.barna.org/barna-update/article/14media/36-barna-technology-study-social-networks-online-entertainment-and-churchpodcasts?social+media.

Blake, M. (2005). Stations of the cross: How evangelical Christians are creating an alternative universe of faith based news. Columbia Journalism Review, 44(1) pp. 32-39.

Blumler, J.G. and Katz, E. (Eds.). (1974). The uses of mass communications: Current perspectives on gratifications research. Beverly Hills, CA: Sage.

Bourgault, L.M. (1985). The PTL Club and protestant viewers: An ethnographic study. Journal of Communication, 35(1) pp. 132-148.

Boyd, S.C. (2007). Black men worshipping: Intersecting anxieties of race, gender and Christian embodiment. Unpublished Ph.D. Dissertation (Emory University).

Carey, J.W. , and Kreiling, A.L. (1974). Popular culture and uses and gratifications: Notes toward an accommodation. In J.G. Blumler and E. Katz (Eds.). The uses of mass communications: Current perspectives on gratifications research. (pp. 225-248). London: Sage.

Creswell, J.W. (1994). Research design: Qualitative and quantitative approaches. Thousand Oaks, CA: Sage.

Drumheller, K. (2005). Millennial Dogma: A fantasy theme analysis of the millennial generation's 
uses and gratifications of religious content media. Journal of Communication and Religion, 28(1), pp. 47-70.

Fetterman, D.M. (1989). Ethnography: Step by step. Newbury Park, CA: Sage.

Frederick, J.G. (2005). The signifying gay: An exploration of communicative practices of black gay men in the church. Unpublished Ph.D. Dissertation (Howard University).

Frederick, M.F. (2003). Between Sundays: Black women and everyday struggles of faith. Berkeley and Los Angeles, CA: University of California Press.

Gertz, C. (1973). The interpretation of cultures. New York: Basic Books.

Gooch, C.R. (1996). Rappin' for the Lord: The uses of gospel rap and contemporary music in black religious communities. In D.A. Stout and J.A. Buddenbaum (Eds.), Religion and Mass Media: Audiences and Adaptations (pp. 228-242). Thousand Oaks, CA: Sage.

Hertzog, H. (1942). Motivations and gratifications of serial listeners. In P.F. Lazersfeld and F. Stanton (Eds.) Radio Research (pp.50-55). New York: Duell, Sloan and Pearce.

Jorgensen, D.L. (1989). Participant observation: A methodology for human studies. Newbury Park, CA: Sage.

Kvale, S. (1996). InterViews: An introduction to qualitative research interviewing. Thousand Oaks, CA: Sage.

Lemish, D. (1985). Soap opera viewing in college: A naturalistic inquiry. Journal of Broadcasting and Electronic Media, 29 (3) pp. 275-293.

Lincoln, Y.S. and Guba, E.G. (1995). Naturalistic inquiry. Beverly Hills, CA: Sage.

Lofland, J., and Lofland, L.H. (1995). Analyzing social settings: A guide to qualitative observation and analysis $\left(3^{\text {rd }}\right.$. Ed.). Belmont, CA: Wadsworth.

Massey, K. B. (1995). Analyzing the uses and gratifications concept of audience activity within a qualitative approach: Media encounters during the 1989 Loma Prieta earthquake disaster. Journal of Broadcasting and Electronic Media, 39(3), pp. 328-349.

May, R.A. (1999). Tavern culture and television viewing: The influence of local viewing culture on patron's reception of television programs. Journal of Contemporary Ethnography, 28(1), pp. 69-99. 
Miles, M.B., and Huberman, A. M. (1994). Qualitative data analysis: A sourcebook for new methods $\left(2^{\text {nd }}\right.$. Ed.). Thousand Oaks, CA: Sage.

Newhagen, J., and Rafaeli, S. (1996). Why communication researchers should study the Internet: A dialogue. Journal of Communication, 46(1), pp. 4-13.

Novek, E.M. (1995). West urbania: An ethnographic study of communication practices in inner-city youth culture. Communication Studies, 46(3), pp. 169-186.

Patton, M.Q. (1990). Qualitative evaluation and research methods. Newbury Park, CA: Sage.

Pew Research Center for the People and the Press. (2001, Dec. 6). Post September 11 attitudes:

Religion more prominent: Muslim Americans more accepted. Retrieved July 22, 2010 from http://people-press-org/report/144/post-september-11-attitudes.

Richardson, J.D. (2003). Uses and gratifications of Agnostic refuge: Case study of a skeptical online congregation. Journal of Media and Religion, 2(4), pp. 237-250.

Rockquemore, K.A. and Laszloffy, T. (2005) Raising biracial children. Lanham, MD.: AltaMira Press.

Ruggiero, T.E. (2000). Uses and gratifications theory in the $21^{\text {st }}$ century. Mass Communication and Society, 3(1), pp. 3-37.

Sanjek, R. (1990). Fieldnotes: The makings of anthropology. Ithaca, NY: Cornell University Press.

Schwandt, T.A. (1994). Constructivist, interpretivist approaches to human inquiry. In N.K. Denzin and Y.S. Lincoln (Eds.). Handbook of Qualitative Research. (pp. 118-137). Thousand Oaks, CA: Sage.

Urista, M.A., Dong, Q., Day, K.D. (2009). Explaining why young adults use myspace and facebook through uses and gratifications theory. Human Communication, 12(2), pp. 215-229.

\section{Endnotes}

\footnotetext{
${ }^{\mathrm{i}}$ According to the National Council of Churches 2010 Yearbook of American and Canadian Churches. The group is called the National Baptist Convention, USA Inc.

ii According to the website www.Census.gov, the mean household income is $\$ 39,865$ per year for this town.

iii Data obtained from the PA Dept of Labor and Industry's Center for Workforce Information and Analysis. The report contained the unemployment status of this area in mid 2010.

iv Data derived from the FBI website with the report entitled "Offenses known to Law Enforcement by State by City 2008".

${ }^{v}$ Data obtained from an American Community Survey report at www.census.gov .
} 